\title{
Performance, bioenergetic status, and indicators of oxidative stress of environmentally heat-loaded Holstein cows in response to diets inducing milk fat depression
}

\author{
S. Kargar, ${ }^{* 1}$ G. R. Ghorbani,† V. Fievez, $\ddagger$ and D. J. Schingoethe§ \\ *Department of Animal Sciences, College of Agriculture, Shiraz University, Shiraz 71441-65186, Iran \\ †Department of Animal Sciences, College of Agriculture, Isfahan University of Technology, Isfahan 84156-83111, Iran \\ †Laboratory for Animal Nutrition and Animal Product Quality, LANUPRO, Department of Animal Production, Faculty of Bioscience Engineering, \\ Ghent University, Proefhoevestraat 10, 9090 Melle, Belgium \\ §Dairy Science Department, South Dakota State University, Brookings 57007-0647
}

\begin{abstract}
Effects of grain type and dietary oil supplement on production performance, energy balance, metabolic heat production, and markers of liver function of heatloaded lactating dairy cows were evaluated using 8 multiparous Holstein cows $(77.0 \mathrm{~d}$ in milk) in a duplicated $4 \times 4$ Latin square design with a $2 \times 2$ factorial arrangement of treatments. Experimental diets contained either ground barley or ground corn supplemented with either fish oil or soybean oil at $2 \%$ of dietary dry matter. Mean daily maximum temperature, minimum relative humidity, and maximum temperature-humidity index were $35.3^{\circ} \mathrm{C}, 11.3 \%$, and 77.0 , respectively. Dietary treatment did not affect rectal temperature $\left(38.9^{\circ} \mathrm{C}\right)$, but respiration rate tended to decrease in cows fed fish oil versus soybean oil. Dry matter intake decreased for the fish oil-supplemented diets (21.1 vs. $24.3 \mathrm{~kg} / \mathrm{d}$ ), which was negatively correlated with plasma concentrations of alkaline phosphatase $(\mathrm{r}=-0.45 ; \mathrm{n}=32)$ and malondialdehyde $(\mathrm{r}=-0.26 ; \mathrm{n}=32)$. Actual milk yield $(41.9 \mathrm{~kg} / \mathrm{d})$ and energy-corrected milk yield $(36.6 \mathrm{~kg} / \mathrm{d})$ were not affected by grain type, whereas feeding fish oil decreased milk yield as compared with soybean oil (40.4 vs. $43.4 \mathrm{~kg} / \mathrm{d})$. Milk fat depression occurred in all dietary treatments, especially when cows were fed fish oil because of the presence of polyunsaturated FA in the diets. trans-10 C18:1 was negatively correlated with milk fat yield $(\mathrm{r}=-0.38 ; \mathrm{n}=32)$. Daily milk cis-9,trans-11 C18:2 secretion was $29.6 \%$ less in cows fed barley- versus corn-based diets but $31.8 \%$ greater in cows fed fish oil as compared with cows fed soybean oil. Because of a lower dry matter intake, metabolic heat production was decreased in cows fed fish oil relative to cows fed soybean oil. Although feeding fish oil versus soybean oil decreased net energy for both maintenance
\end{abstract}

Received November 13, 2014.

Accepted March 24, 2015.

${ }^{1}$ Corresponding author: skargar@shirazu.ac.ir or skargar@wisc.edu and lactation, net energy balance remained unchanged across treatments. In vivo plasma lipoperoxidation was greater in cows fed fish oil versus soybean oil, which substantiated increased susceptibility of plasma lipoperoxidation when cows were fed fish oil. Plasma concentration of malondialdehyde was positively correlated with plasma aspartate aminotransferase $(\mathrm{r}=0.38 ; \mathrm{n}$ $=32$ ), which is an indicator of liver function in heatloaded cows. Results suggest that in heat-loaded cows fed diets supplemented with soybean oil versus fish oil, biosynthesis in the mammary gland was prioritized over anabolism and oxidation in peripheral adipose and muscle tissues regardless of type of grain used.

Key words: grain and oil, milk fat depression, heat load, dairy cow

\section{INTRODUCTION}

Heat-stressed dairy cattle are bioenergetically similar to early-lactation cows in that dietary energy may be insufficient to support maximum milk and production of milk components (Moore et al., 2005). Milk yield of heat-stressed dairy cows is usually decreased during the summer (Drackley et al., 2003; Moallem et al., 2010); therefore, increasing performance of cows is of particular interest in many dairy-producing areas of the world. The bioenergetic mechanism by which heat stress affects milk yield and animal health is partially explained by decreased DMI, but also comprises changed endocrine status, decreased rumination and nutrient absorption, and increased maintenance requirements (Moore et al., 2005; Liu et al., 2008; Baumgard and Rhoads, 2012) resulting in a net decrease in nutrient and energy availability for production as well as liver dysfunction and induction of oxidative stress (Ronchi et al., 1999; Bernabucci et al., 2010). Therefore, the decrease in energy intake, resulting in a reduction in energy balance, partially explains why cows lose significant amounts of BW when subjected to heat stress (Bernabucci et al., 2010). Nutritional strategies to alleviate this energy deficit 
traditionally include increasing the energy density of the diet with starchy concentrates or oil supplements (Drackley et al., 2003; Moallem et al., 2010). Decreasing the energy requirement for milk fat synthesis is an alternative tool to improve energy balance during heat stress (Moore et al., 2005). This strategy is particularly relevant because fat is energetically the most expensive component of milk, so that daily milk fat secretion in early lactating cows represents up to $35 \%$ of the net energy intake (Bauman and Currie, 1980). The saved energy may be either partitioned into milk and attenuate or eliminate the harmful effect of environmental heat on production or may be stored in body tissues (Drackley et al., 2003; Moore et al., 2005; Moallem et al., 2010).

According to recent experiments, a decrease in DMI just describes approximately 35 to $50 \%$ of the decreased milk yield of heat-stressed dairy cows (Bernabucci et al., 2010; Wheelock et al., 2010; Baumgard and Rhoads, 2012). The remainder of heat-induced milk yield losses may be partially attributed to liver dysfunction, which has been suggested earlier (Ronchi et al., 1999; Bernabucci et al., 2010), or changes in postabsorptive metabolism (Wheelock et al., 2010; Baumgard et al., 2011; Baumgard and Rhoads, 2012). Liver dysfunction may be displayed by alterations in responsiveness to nutrient supply or endocrine regulators, e.g., as has been illustrated in the case of growthhormone responses (Rhoads et al., 2010). These alterations would directly influence the ability of the liver to coordinate whole-body nutrient flux by changing key metabolic pathways such as gluconeogenesis. Accordingly, heat-induced changes in liver gluconeogenic gene expression might be linked to variation in the supply of precursors for the synthesis of milk solids (Rhoads et al., 2011). Therefore, heat-induced decreased milk lactose secretion (the key osmotic regulator of milk yield) may simply reflect changed rates of liver gluconeogenesis, which would finally decrease glucose delivery to the mammary gland and thereby reduce milk yield. In other cases, liver glucose production in heat-stressed cows was similar to that in thermal-neutral cows on a similar plane of nutrition. Nevertheless, heat-stressed cows yielded almost $400 \mathrm{~g}$ less glucose per day as compared with pair-fed, thermal-neutral counterparts (Wheelock et al., 2010), suggesting an increased glucose use by extramammary tissues, which might be another key mechanism explaining the reduction in milk yield under heat stress (Wheelock et al., 2010; Baumgard et al., 2011; Baumgard and Rhoads, 2012).

Recent experiments conducted in thermoneutral conditions have confirmed that a more rapidly fermented starch type (wheat or barley grain) versus a slowly fermented starch type (corn grain) caused milk fat de- pression (MFD) in lactating dairy cows, with varying effects on DMI and milk production (Cabrita et al., 2009; Mohammed et al., 2010). Another strategy to reduce milk fat secretion includes supplementation of marine products. Previous research demonstrated that the feeding of fish oil versus extruded soybeans also decreased DMI and milk yield (Whitlock et al., 2002). AbuGhazaleh et al. (2002) showed neither MFD nor difference in DMI and milk yield of cows fed fish oil compared with cows fed extruded soybeans. However, in an experiment by Alizadeh et al. (2012), cows fed $2 \%$ fish oil experienced MFD but maintained milk yield although DMI was depressed.

Information is lacking on the effect of type of dietary grain differing in ruminal fermentability in combination with oil supplements on performance and energy-partitioning priorities of heat-stressed cows. We hypothesized that the greater starch digestibility of barley grain versus corn grain in the rumen would induce MFD and improve milk yield if DMI is maintained and if extra energy is not directed to body reserves by greater insulin secretion. Furthermore, we also hypothesized that soybean oil would induce a more modest MFD as compared with fish oil but could enhance milk production if soybean oil better maintains DMI as compared with fish oil. Therefore, the objective of this experiment was to determine the effects of, and interactions between, grain type and oil supplement on the production performance, bioenergetic status, and metabolic heat production (MHP). Moreover, given the interaction of heat stress with liver metabolism, markers of liver function were monitored as well as the antioxidant status of heat-stressed Holstein cows.

\section{MATERIALS AND METHODS}

\section{Animals, Experimental Design, and Treatments}

The Isfahan University of Technology (IUT) Laboratory Animal Care Advisory Committee approved all procedures involving animals. The experiment was conducted (June to September 2011) in Lavark at the Farm Animal Research and Teaching Unit of IUT. Experimental details have been presented in a companion manuscript (Kargar et al., 2013) and are summarized in the following. Eight lactating, multiparous Holstein cows $(\mathrm{BW}=670.3 \pm 45.8$; parity $=3.3 \pm 1.3$; mean $\pm \mathrm{SD})$ averaging $77 \pm 22.1 \mathrm{DIM}$ were used in a replicated $4 \times 4$ Latin square design with 25 -d periods. Each experimental period consisted of an 18-d diet adaptation period and a 7-d collection period. Cows within a square were assigned randomly to dietary treatments. Cows were blocked into 2 squares of 4 cows each based upon milk production and DIM and were 
KARGAR ET AL.

Table 1. Ingredients and chemical composition of experimental $\operatorname{diets}^{1}$ on DM basis ${ }^{2}$

\begin{tabular}{|c|c|c|c|c|}
\hline Item & $\mathrm{BF}$ & $\mathrm{BS}$ & $\mathrm{CF}$ & CS \\
\hline \multicolumn{5}{|l|}{ Ingredient composition, $\%$ of DM } \\
\hline Corn silage & 19.00 & 19.00 & 19.00 & 19.00 \\
\hline Alfalfa hay & 21.00 & 21.00 & 21.00 & 21.00 \\
\hline Beet pulp & 4.22 & 4.22 & 4.22 & 4.22 \\
\hline Barley grain, ground & 33.20 & 33.20 & - & \\
\hline Corn grain, ground & — & - & 28.50 & 28.50 \\
\hline Soybean meal & 14.02 & 14.02 & 2.45 & 2.45 \\
\hline Canola meal, pelleted & 2.50 & 2.50 & 17.80 & 17.80 \\
\hline Corn gluten meal & 0.96 & 0.96 & 1.93 & 1.93 \\
\hline Fish oil & 2.00 & - & 2.00 & \\
\hline Soybean oil & - & 2.00 & - & 2.00 \\
\hline Mepron $^{3}$ & 0.05 & 0.05 & 0.05 & 0.05 \\
\hline Sodium bicarbonate & 0.75 & 0.75 & 0.75 & 0.75 \\
\hline Calcium carbonate & 0.65 & 0.65 & 0.65 & 0.65 \\
\hline Vitamin E premix ${ }^{4}$ & 0.10 & 0.10 & 0.10 & 0.10 \\
\hline Vitamin $\mathrm{A}, \mathrm{D}_{3}$, and $\mathrm{E}$ premix ${ }^{5}$ & 1.18 & 1.18 & 1.18 & 1.18 \\
\hline Salt & 0.42 & 0.42 & 0.42 & 0.42 \\
\hline \multicolumn{5}{|l|}{ Chemical composition } \\
\hline $\mathrm{DM}, \%$ & $54.61(1.02)$ & $55.42(1.45)$ & $54.05(1.78)$ & $54.48(1.64)$ \\
\hline $\mathrm{OM}, \%$ of $\mathrm{DM}$ & $49.44(0.72)$ & $50.20(1.27)$ & $49.34(1.21)$ & $49.76(1.27)$ \\
\hline $\mathrm{CP}, \%$ of $\mathrm{DM}$ & $16.04(0.56)$ & $15.88(0.42)$ & $15.76(0.91)$ & $15.78(1.30)$ \\
\hline $\mathrm{NFC}{ }^{6} \%$ of DM & $38.12(0.52)$ & $38.58(1.03)$ & $40.68(1.07)$ & $40.70(0.63)$ \\
\hline $\mathrm{NDF}, \%$ of DM & $32.23(1.07)$ & $32.05(0.51)$ & $29.92(1.52)$ & $29.48(0.69)$ \\
\hline Ether extract, \% of DM & $4.08(0.20)$ & $4.08(0.69)$ & $4.94(0.03)$ & $4.85(0.17)$ \\
\hline Ash, $\%$ of DM & $9.46(0.31)$ & $9.41(0.34)$ & $8.70(0.18)$ & $8.67(0.14)$ \\
\hline $\mathrm{NE}_{\mathrm{L}}{ }^{7}{ }^{7} \mathrm{Mcal} / \mathrm{kg}$ of DM & 1.70 & 1.70 & 1.72 & 1.72 \\
\hline \multicolumn{5}{|c|}{$\begin{array}{l}{ }^{1} \mathrm{BF}=\text { barley-based diet supplemented with fish oil; } \mathrm{BS}=\text { barley-based diet supplemented with soybean oi } \\
\mathrm{CF}=\text { corn-based diet supplemented with fish oil; and } \mathrm{CS}=\text { corn-based diet supplemented with soybean oil. } \\
{ }^{2} \text { Standard deviations are within parentheses. } \\
{ }^{3} \text { Mepron M85 (M85; Degussa AG, Hanau, Germany). } \\
{ }^{4} \text { Contains } 500,000 \mathrm{IU} \text { of vitamin E per kilogram. } \\
{ }^{5} \text { Contains } 15,000,000 \text { IU of vitamin A, 400,000 IU of vitamin } \mathrm{D}_{3} \text {, and } 6,000 \mathrm{IU} \text { of vitamin E per kilogram. } \\
{ }^{6} \mathrm{NFC}=100-(\mathrm{CP}+\mathrm{NDF}+\text { ether extract }+ \text { ash). } \\
{ }^{7} \text { Calculated from NRC }(2001) .\end{array}$} \\
\hline
\end{tabular}

assigned within blocks to 1 of the 4 experimental diets with a $2 \times 2$ factorial arrangement: (1) barley-based diet supplemented with fish oil at $2 \%$ of dietary DM; (2) barley-based diet supplemented with soybean oil at $2 \%$ of dietary DM; (3) corn-based diet supplemented with fish oil at $2 \%$ of dietary DM; and (4) corn-based diet supplemented with soybean oil at $2 \%$ of dietary DM (Table 1). Treatment diets were randomly assigned after blocking to minimize carryover effects. Cows were housed individually in box stalls $(4 \mathrm{~m} \times 4 \mathrm{~m})$ located in a roofed area with open sides. Each box stall was equipped with a concrete feed bunk and automatic water troughs. Clean wood shavings and sand were used for bedding and refreshed twice daily. Cows were allowed to exercise in an outdoor lot daily from 1700 to $1800 \mathrm{~h}$. Diets were formulated to meet or exceed the Cornell Net Carbohydrate and Protein System (version 5.0) nutrient allowance for a lactating dairy cow weighing $673 \mathrm{~kg}$ and producing $43 \mathrm{~kg} / \mathrm{d}$ of milk with $3.0 \%$ milk true protein and $3.2 \%$ fat and with $24.1 \mathrm{~kg}$ of DMI. Fish oil or soybean oil was incorporated into the concentrate fraction and then added to the TMR. Di- etary ingredients were mixed for approximately $8 \mathrm{~min}$ in a TMR mixer wagon (Fan Avaran Keshavarzi Arya Co., Isfahan, Iran). After mixing, the ration was transferred to a feed cart (Iran Plast Co., Isfahan, Iran) from which cows were fed. Feed was supplied twice daily at 0900 and $1500 \mathrm{~h}$ in amounts that allowed 10\% refusals.

Cows were weighed immediately before the morning feeding at the beginning and end of each period, and these weights were used to calculate BW changes and tissue energy gain of cows for each experimental period (NRC, 2001). Furthermore, BW were used to calculate net energy balance (NEBAL) using the following equation: NEBAL $=$ net energy intake $-\left(\mathrm{NE}_{\mathrm{M}}+\mathrm{NE}_{\mathrm{L}}\right)$. Net energy intake was calculated by multiplying the DMI by the net energy of the diet. The net energy required for maintenance was calculated according to the NRC (2001) using the following equation: $\mathrm{NE}_{\mathrm{M}}(\mathrm{Mcal} / \mathrm{d})=$ $\left(0.08 \times \mathrm{BW}^{0.75}\right) \times 1.2$ to account for increased maintenance due to heat stress (NRC, 1981). The $\mathrm{NE}_{\mathrm{L}}$ was also calculated according to the NRC (2001) with the observed milk yield and concentrations of milk fat, milk protein, and milk lactose using the following equation: 
$\mathrm{NE}_{\mathrm{L}}(\mathrm{Mcal} / \mathrm{d})=$ milk yield $\times[0.0929 \times$ milk fat $(\%)$ $+0.0547 \times$ milk protein $(\%)+0.0395 \times$ milk lactose $(\%)$. Then, values for $\mathrm{NE}_{\mathrm{L}}$ and tissue energy gain were used to calculate energy efficiency using the following equation: energy efficiency $=[$ milk energy (Mcal of $\mathrm{NE}_{\mathrm{L}}$ ) + tissue energy gain (Mcal of $\mathrm{NE}_{\mathrm{L}}$ )] $/ \mathrm{kg}$ of $\mathrm{DM}$. Throughout the experiment, BCS was recorded at the beginning and end of each period by the same trained observer using a scale from 1 (emaciated) to 5 (obese) in 0.25-point increments using a scoring procedure particularly emphasizing on certain anatomical sites of the pelvic and loin area (Ferguson et al., 1994). Scored values were used to calculate BCS changes of cows over each experimental period. Because body condition scoring is a subjective estimate of energy reserves, backfat thickness (BFT) was measured using a portable B-mode ultrasound generator (SonoVet $600 \mathrm{~V}$, BCF Technology Ltd., West Lothian EH54 9BJ, Scotland, UK) with a linear transducer and a frequency between 5.0 and $6.5 \mathrm{MHz}$ (Kargar et al., 2013).

\section{Feed and Milk Sampling and Analyses}

The TMR amounts offered and refused were measured daily for each cow, with DMI determined daily for each cow. To determine DM and nutrient composition, representative samples of forages (pooled within period), treatment TMR (pooled by diet within period), and individual refusals (pooled by cow within period) were collected immediately before the morning feeding during the 5-d collection period. All samples were frozen immediately at $-20^{\circ} \mathrm{C}$ until analysis. Dry matter, CP, NDF, ether extract, and ash content of all samples were analyzed as described by Kargar et al. (2012, 2014a). The nonfibrous carbohydrate component was calculated as $100-(\mathrm{CP}+\mathrm{NDF}+$ ether extract + ash) (NRC, 2001).

Cows were milked 3 times daily at 0200, 1000, and $1800 \mathrm{~h}$ in a herringbone milking parlor. Milk yield for all cows was recorded and sampled at each milking during the last $7 \mathrm{~d}$ of each period. Milk samples were composited in proportion to milk yield, preserved with potassium dichromate, stored at $4^{\circ} \mathrm{C}$, and submitted to the Central Milk Testing Laboratory of IUT (IUT, Isfahan, Iran) for fat, protein, and lactose analyses using an infrared analyzer (MilkoScan 134 BN; Foss Electric, Hillerød, Denmark). Milk fat and protein yield $(\mathrm{kg} / \mathrm{d})$ were calculated, for the last $7 \mathrm{~d}$ of each experimental period, based on the product of the milk production yield and milk composition at each milking on those days. Energy-corrected milk was calculated as ( $\mathrm{kg}$ of milk $\times 0.3246)+(\mathrm{kg}$ of milk fat $\times 12.96)+(\mathrm{kg}$ of milk protein $\times 7.04)($ Kargar et al., 2012).

\section{Milk FA Analyses}

At the 3 daily milkings, additional samples were collected for FA analysis. A daily sample was composited based on milk fat yield and stored in plastic vials (Yasa Teb Co., Isfahan, Iran) without preservative at $-20^{\circ} \mathrm{C}$ until the end of the experiment before being lyophilized (OSK 2139 Freeze Dryer Mechanical Refrigerated, Ogawa Seiki Co. Ltd., Tokyo, Japan) and FA analyses. Lyophilized milk samples $(250 \mathrm{mg})$ were weighed in a $25-\mathrm{mL}$ tube with screw cap to which $2.0 \mathrm{~mL}$ of prewarmed $\left(60-65^{\circ} \mathrm{C}\right)$ distilled water was added. The tube was closed and vortexed for $1 \mathrm{~min}$. Samples were left at room temperature $\left(20^{\circ} \mathrm{C}\right)$ for $15 \mathrm{~min}$, where after milk fat was extracted using the mini Röse-Gottlieb method (Chouinard et al., 1997), FA were methylated (Stefanov et al., 2010), and the profile of FAME was determined by gas chromatography [Agilent Technologies 7890A GC System (Agilent Technologies Inc., Santa Clara, CA) equipped with a flame ionization detector]. Samples were injected by split injection (split ratio 1:50). The carrier gas was hydrogen, and inlet pressure was $246.38 \mathrm{kPa}$. Fatty acid peaks were identified based on their retention times. Separation of FAME was realized with a Supelco column (SP-2560, Sigma-Aldrich, Buchs, Switzerland; $75 \mathrm{~m} \times 180 \mu \mathrm{m} \times 0.14 \mu \mathrm{m})$. The temperature program ran from a starting temperature of $70^{\circ} \mathrm{C}$ for $2 \mathrm{~min}$, increased $15^{\circ} \mathrm{C} / \mathrm{min}$ until $150^{\circ} \mathrm{C}$, and then increased $1^{\circ} \mathrm{C} / \mathrm{min}$ from $150^{\circ} \mathrm{C}$ until $165^{\circ} \mathrm{C}$. Then, $165^{\circ} \mathrm{C}$ was held for $12 \mathrm{~min}$; from $165^{\circ} \mathrm{C}$ until $170^{\circ} \mathrm{C}$, the temperature was increased $2^{\circ} \mathrm{C} / \mathrm{min}$, with $170^{\circ} \mathrm{C}$ held for 5 min. From $170^{\circ} \mathrm{C}$ until $215^{\circ} \mathrm{C}$, an increase of $5^{\circ} \mathrm{C} /$ min was applied, with the final temperature kept for $10 \mathrm{~min}$. Fatty acid methyl esters were determined with Agilent ChemStation software (B.04.03, Agilent Technologies Inc.; Edition 9/2010), and tridecanoic acid (C13:0; as triacylglyceride; Sigma, Bornem, Belgium) was used as internal standard. Fatty acids were expressed as grams per $100 \mathrm{~g}$ of FAME. Fatty acid peaks were identified through mixtures of methyl ester standards (BR2 and BR3, Larodan Fine Chemicals AB, Malmö, Sweden; Supleco 37, Supleco Analytical, Bellefonte, PA; PUFA-3, Matreya LLC, Pleasant Gap, PA), based on retention time. Short-chain FA were corrected for their respective theoretical relative response factors (Ackman and Sipos, 1964; Wolff et al., 1995).

\section{Blood Sampling and Analyses}

Blood was collected in tubes $(7 \mathrm{~mL}$ per sample; Vacutainer, Becton Dickinson, Rutherford, NJ) containing sodium heparin from each cow by puncture of the coccygeal vein at $3 \mathrm{~h}$ after the a.m. feeding on $\mathrm{d} 20$ of each period and placed immediately on ice. Samples were 
centrifuged at $1,850 \times g$ for $20 \mathrm{~min}$ at $4^{\circ} \mathrm{C}$ for plasma separation, and each sample was divided into 3 aliquots and frozen at $-20^{\circ} \mathrm{C}$ until analysis. Concentrations of plasma glucose, total cholesterol, total triacylglycerols, high-density lipoprotein cholesterol, low-density lipoprotein cholesterol, aspartate transaminase (AST; or serum glutamic oxaloacetic transaminase), alanine transaminase (ALT; or serum glutamic pyruvate transaminase), alkaline phosphatase (ALP), creatine kinase (CK; Pars Azmoon Co., Tehran, Iran), and total antioxidant status (Randox Laboratories Ltd., Crumlin, UK) were determined automatically by using standard test kits on an ALCYON 300i automatic analyzer (Abbott Laboratories Ltd., Chicago, IL). The analyzer was calibrated and controls assayed daily according to the manufacturer's instructions to ensure acceptable assay performance. Plasma insulin (Pars Azmoon Co.) and NEFA (Randox Laboratories Ltd.) concentrations were determined by the enzymatic colorimetry methods using an ELISA plate reader $\mathrm{EL}_{\mathrm{X}} 808$ Ultra Microplate (Bio-Tek Instruments Inc., Winooski, VT). The concentration of plasma malondialdehyde (MDA), which is a degradation product of lipid peroxidation, was determined by thiobarbituric acid reacting substances method, in which the absorbance of a colored complex that is formed from the reaction of MDA with 2-thiobarbituric acid in acid environment is measured at 532 nm (Wullepit et al., 2012). Furthermore, susceptibility of plasma lipids to lipoperoxidation was evaluated by measuring the in vitro conjugated dienes $(\mathbf{C D})$ generation induced by the addition of copper ions. Copper chloride $(10 \mathrm{mM})$ was added to each plasma sample, and absorbance of UV light was continuously monitored at $245 \mathrm{~nm}$ for $90 \mathrm{~min}$ (at 5-min intervals) using a UV-VIS Recording Spectrophotometer (UV 2100, Shimadzu Co., Kyoto, Japan; Schnitzer et al., 1998). Basal and maximum absorbance at $245 \mathrm{~nm}$ and the net area under the curve of plasma CD were computed by the trapezoid method and treated as the final results. The revised quantitative insulin-sensitivity check index (RQUICKI) as relative insulin sensitivity measure, was estimated as RQUICKI $=1 /[\log ($ glucose $)+\log$ (insulin) $+\log$ (NEFA)] according to Holtenius and Holtenius (2007).

\section{Climatic Data, Respiration Rate, and Rectal Temperature}

The Najaf Abad (a branch of Isfahan) Meteorological Network recorded weather data daily, and this information was used to compute the temperature-humidity index (THI) according to following formula: $\{$ THI $=$ $(0.8 \times$ maximum temperature $)+[($ minimum relative humidity/100 $) \times($ maximum temperature -14.4$)+$
46.4]; Mirzaei et al., 2011\}. Respiration rates were determined daily during data-collection periods at 1430 $\mathrm{h}$ for 3 separate minutes by counting the number of breaths in a 15-s period and then multiplying this by 4 to compute breaths per minute. Rectal temperature was also measured at the same time as respiration rate using a clinical veterinary thermometer (Yasa Teb Co.) inserted in the rectum.

\section{Statistical Analyses}

Data were composited within period and subjected to the MIXED MODEL procedure of SAS (SAS Institute Inc., 2003) to account for effects of square, period within square, cow within square, treatments (grain type and oil supplement), and the interaction between grain type (barley grain vs. corn grain) and oil supplement (fish oil vs. soybean oil). The REML method was used to estimate least squares means, and the Kenward-Roger method was used to calculate denominator degrees of freedom. The Pearson correlation coefficients were estimated using the CORR procedure of SAS (SAS Institute Inc., 2003). Normality of distribution and homogeneity of variance for residuals were tested using PROC UNIVARIATE (SAS Institute Inc., 2003). In case of non-normality, parameters were normalized by $\log$ transformation before analysis to generate a normal distribution. Effects of the factors were declared significant at $P \leq 0.05$ unless otherwise noted, and trends were discussed at $P \leq 0.10$.

\section{RESULTS}

As shown in Figure 1, the average maximum THI, relative humidity, and maximum temperature were $79.3,11 \%$, and $38^{\circ} \mathrm{C}$ for period $1 ; 77.7,11 \%$, and $36^{\circ} \mathrm{C}$ for period $2 ; 77.1,13 \%$, and $35^{\circ} \mathrm{C}$ for period 3 ; and $74.0,10 \%$, and $32^{\circ} \mathrm{C}$ for period 4 , respectively. Similarly, those values were $77.7,11 \%$, and $36^{\circ} \mathrm{C}$ for datacollection wk $1 ; 78.5,10 \%$, and $37^{\circ} \mathrm{C}$ for data-collection wk $2 ; 73.3,20 \%$, and $30^{\circ} \mathrm{C}$ for data-collection wk 3 ; and $73.1,9 \%$, and $31^{\circ} \mathrm{C}$ for data-collection wk 4 , respectively. Treatment did not affect rectal temperature, whereas oil supplementation (fish oil vs. soybean oil) tended to reduce respiration rate $(P=0.08$; Table 2$)$, but no interaction between grain and oil supplement was observed. Grain type (barley grain vs. corn grain) did not affect energy intake (ME and NE), but cows fed diets based on barley grain tended $(P=0.09$; Table 2$)$ to have greater DMI as compared with cows fed cornbased diets. Feeding fish oil decreased DMI and energy intake as compared with soybean oil (21.1 vs. 24.3 $\mathrm{kg} / \mathrm{d} ; P<0.001)$. Actual and ECM yields, and yield of milk components (i.e., fat, protein, and lactose), were 


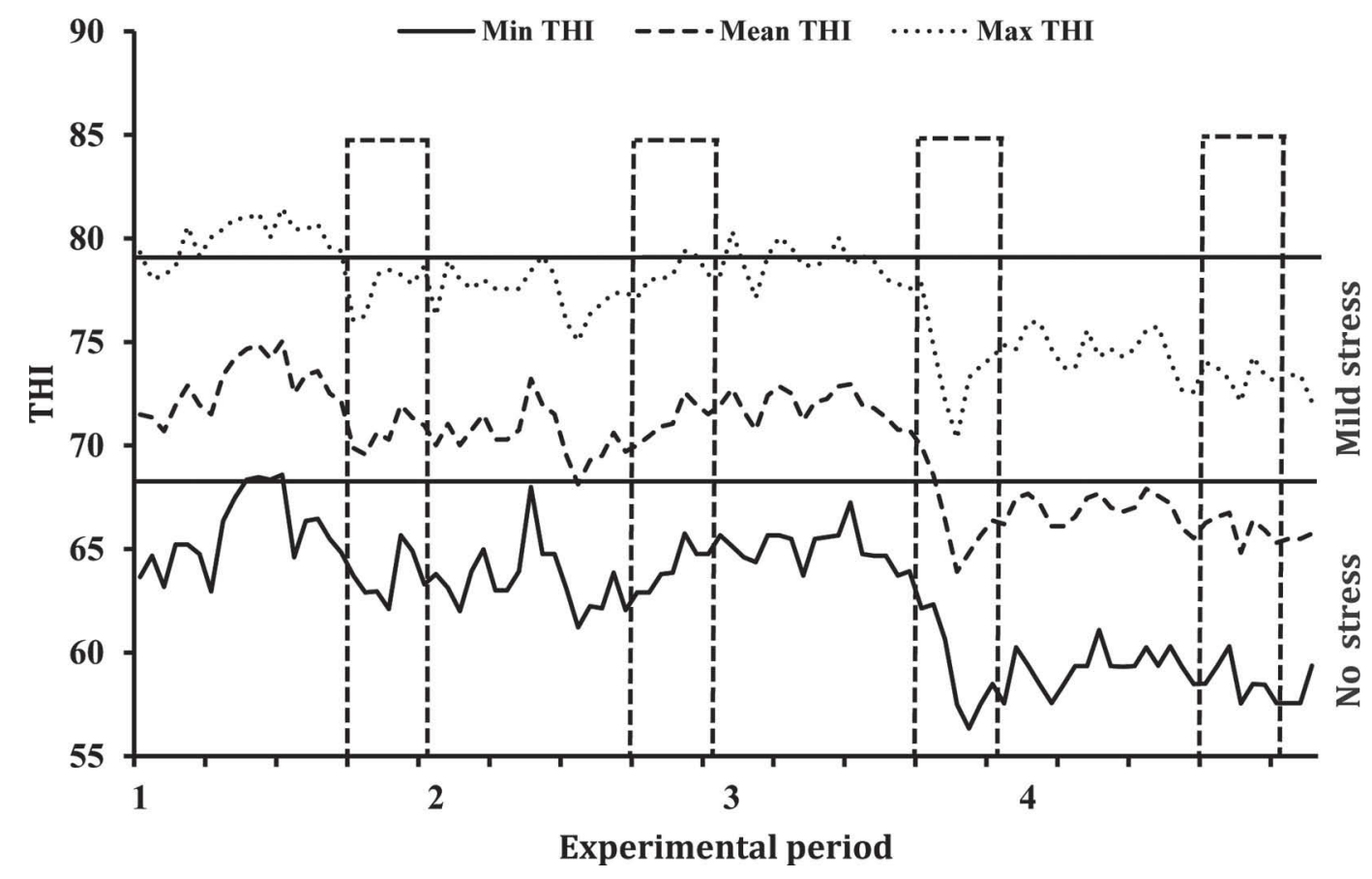

Figure 1. Temporal pattern of minimum (Min), mean, and maximum (Max) temperature-humidity index (THI) over the experimental periods. Dashed boxes indicate sampling week within each period.

not different between barley- and corn-based diets. Dietary grain type and oil supplement did not have an interactive effect on milk fat yield. Decreased intakes of the fish oil-supplemented diets were associated with reduced milk production and yield of milk components as compared with soybean oil-supplemented diets. Efficiency of both DMI and $\mathrm{NE}_{\mathrm{L}}$ intake use for ECM was similar among treatments.

Treatment effects on milk FA secretion are presented in Table 3. Main treatment effects did not interact for secretion of milk FA. Secretion of short-chain FA was similar between barley- and corn-based diets, averaging $114.8 \mathrm{~g} / \mathrm{d}$, whereas secretion of medium-chain FA and long-chain FA increased $(478.0$ vs. $423.4 \mathrm{~g} / \mathrm{d} ; P=$ $0.01)$ and tended to decrease $(390.0$ vs. $428.5 \mathrm{~g} / \mathrm{d} ; P$ $=0.11)$ in diets containing barley grain as compared with corn-based diets, respectively. This was, in part, because of greater secretion of C16:0 (306.0 vs. 265.1 $\mathrm{g} / \mathrm{d} ; \quad P=0.01)$ and lesser secretion of C18:1 (259.3 vs. $287.4 \mathrm{~g} / \mathrm{d} ; P=0.05)$ in barley- versus corn-based diets. Secretion of saturated FA was not significantly altered with dietary grain type, whereas secretion of unsaturated FA tended to decrease (365.3 vs. 394.3 $\mathrm{g} / \mathrm{d} ; P=0.07)$ in barley- compared with corn-based diets. Although secretions of trans-10 C18:1 (28.9 g/d) and trans-10,cis-12 CLA $(0.16 \mathrm{~g} / \mathrm{d})$ were not affected by grain type, secretion of trans-11 C18:1 (16.3 vs. 23.5 $\mathrm{g} / \mathrm{d} ; P=0.05)$ and thereby cis-9,trans-11 CLA (10.5 vs. $14.9 \mathrm{~g} / \mathrm{d} ; P=0.01$ ), which showed a strong positive correlation $(\mathrm{r}=0.97 ; P \leq 0.01)$, were lesser in barleycompared with corn-based diets.

Fatty acid secretion was changed with the addition of fish oil compared with soybean oil (Table 3). With the fish oil-supplemented diets, yields of short-chain FA (88.1 vs. $141.6 \mathrm{~g} / \mathrm{d} ; P<0.001$ ), medium-chain FA (407.6 vs. $493.9 \mathrm{~g} / \mathrm{d} ; P<0.001$ ), and long-chain FA (318.6 vs. $499.9 \mathrm{~g} / \mathrm{d} ; P<0.001)$ were less relative to soybean oil-supplemented diets. Secretion of C16:0 (257.4 vs. $313.8 \mathrm{~g} / \mathrm{d} ; P=0.001)$ and total $\mathrm{C} 16: 1$ (33.1 vs. $26.1 \mathrm{~g} / \mathrm{d} ; P<0.001)$ decreased and increased in fish oil- versus soybean oil-supplemented diets, respectively. Compared with soybean oil-supplemented diets, fish oil supplementation of dairy cow diets tended to increase and increased secretion of trans-11 C18:1 (22.9 vs. $16.9 \mathrm{~g} / \mathrm{d} ; P=0.11)$ and cis-9,trans-11 CLA (14.5 vs. $11.0 \mathrm{~g} / \mathrm{d} ; P=0.05)$, respectively. In addition, secretion of trans-10 C18:1 (41.8 vs. $16.0 \mathrm{~g} / \mathrm{d} ; P<0.001$ ) and trans-10, cis- 12 CLA (0.14 vs. $0.18 \mathrm{~g} / \mathrm{d} ; P=0.09)$ increased and tended to decrease in fish oil- versus soybean oil-supplemented diets, respectively. With the fish oil-supplemented diets, secretion of C18:0 (40.9 vs. $114.6 \mathrm{~g} / \mathrm{d} ; P<0.001)$ and total $\mathrm{C} 18: 1$ (222.3 vs. 324.4 $\mathrm{g} / \mathrm{d} ; P<0.001)$ decreased and increased, respectively, compared with soybean oil-supplemented diets. Milk fat yield showed correlations with $\mathrm{C} 18: 0(\mathrm{r}=0.79 ; P \leq$ $0.01), \mathrm{C} 18: 1(\mathrm{r}=0.82 ; P \leq 0.01)$, and trans-10 C18:1 (r $=-0.38 ; P \leq 0.05)$ but not with trans-10, cis-12 CLA $(\mathrm{r}=0.18 ; P>0.10)$. As expected milk secretion of 
Table 2. Rectal temperature, respiration rate, intake, milk yield and milk composition, and feed efficiency as influenced by grain and oil sources

\begin{tabular}{|c|c|c|c|c|c|c|c|c|}
\hline Item & \multicolumn{4}{|c|}{$\operatorname{Diet}^{1} \mathrm{LSM}$} & $\mathrm{SE}$ & \multicolumn{3}{|c|}{$P$-value ${ }^{2}$} \\
\hline Respiration rate, breath/min & 57.6 & 62.6 & 59.1 & 62.3 & 2.62 & 0.79 & 0.08 & 0.69 \\
\hline DMI, $\mathrm{kg} / \mathrm{d}$ & 21.7 & 24.6 & 20.5 & 24.0 & 0.74 & 0.09 & $<0.001$ & 0.54 \\
\hline $\mathrm{NE}_{\mathrm{L}}$ intake, $\mathrm{Mcal} / \mathrm{d}$ & 36.8 & 41.8 & 35.3 & 41.2 & 1.26 & 0.23 & $<0.001$ & 0.59 \\
\hline $\mathrm{ME}$ intake, Mcal/d & 56.3 & 63.9 & 54.4 & 63.5 & 1.94 & 0.39 & $<0.001$ & 0.57 \\
\hline \multicolumn{9}{|c|}{ Yields of milk and milk composition, $\mathrm{kg} / \mathrm{d}$} \\
\hline Fat & 0.91 & 1.28 & 0.90 & 1.24 & 0.08 & 0.64 & $<0.001$ & 0.77 \\
\hline Protein & 1.23 & 1.33 & 1.22 & 1.33 & 0.05 & 0.72 & 0.007 & 0.91 \\
\hline Lactose & 2.31 & 2.55 & 2.28 & 2.39 & 0.09 & 0.18 & 0.01 & 0.35 \\
\hline Total solid & 4.55 & 5.19 & 4.48 & 4.99 & 0.22 & 0.32 & $<0.001$ & 0.64 \\
\hline \multicolumn{9}{|l|}{ Milk composition, \% } \\
\hline Fat & 2.24 & 2.89 & 2.25 & 2.91 & 0.14 & 0.91 & $<0.001$ & 0.98 \\
\hline $\mathrm{ECM} / \mathrm{NE}_{\mathrm{L}}$ intake, $\mathrm{kg} / \mathrm{Mcal}$ & 0.93 & 0.95 & 0.94 & 0.94 & 0.03 & 1.00 & 0.54 & 0.54 \\
\hline
\end{tabular}

${ }^{1} \mathrm{BF}=$ barley-based diet supplemented with fish oil; $\mathrm{BS}=$ barley-based diet supplemented with soybean oil; CF = corn-based diet supplemented with fish oil; and CS = corn-based diet supplemented with soybean oil.

${ }^{2}$ Grain = source of dietary grain (barley vs. corn); Oil = source of supplemental oil (fish vs. soy); Grain $\times$ oil $=$ interaction.

${ }^{3}$ Energy-corrected milk $=(\mathrm{kg}$ of milk $\times 0.3246)+(\mathrm{kg}$ of milk fat $\times 12.96)+(\mathrm{kg}$ of milk protein $\times 7.04)($ Kargar et al., 2012$)$.

Table 3. Milk FA yield as influenced by grain and oil sources

\begin{tabular}{|c|c|c|c|c|c|c|c|c|}
\hline $\mathrm{FA}, \mathrm{g} / \mathrm{d}$ & \multicolumn{4}{|c|}{$\operatorname{Diet}^{1} \mathrm{LSM}$} & $\mathrm{SE}$ & \multicolumn{3}{|c|}{$P$-value ${ }^{2}$} \\
\hline Short-chain FA (C4:0-C12:0) & 88.2 & 144.2 & 88.0 & 138.9 & 17.13 & 0.77 & $<0.001$ & 0.78 \\
\hline Long-chain FA (C18:0-C22:6) & 303.3 & 476.8 & 333.9 & 523.1 & 31.38 & 0.11 & $<0.001$ & 0.74 \\
\hline C16:0 & 270.6 & 341.4 & 244.2 & 286.1 & 21.17 & 0.01 & 0.001 & 0.35 \\
\hline Total C16:1 & 35.1 & 26.1 & 31.2 & 26.1 & 2.69 & 0.16 & $<0.001$ & 0.16 \\
\hline C18:1 trans -9 & 4.4 & 4.0 & 5.0 & 4.8 & 0.42 & 0.11 & 0.50 & 0.75 \\
\hline $\mathrm{C} 18: 1$ trans -10 & 44.3 & 16.0 & 39.3 & 16.0 & 5.71 & 0.67 & $<0.001$ & 0.66 \\
\hline C18:1 trans-11 & 18.8 & 13.7 & 27.0 & 20.0 & 5.47 & 0.05 & 0.11 & 0.80 \\
\hline $\mathrm{C} 18: 1$ trans -12 & 8.3 & 6.6 & 9.4 & 7.3 & 0.99 & 0.22 & 0.01 & 0.72 \\
\hline $\mathrm{C} 18: 1$ trans $-13+$ trans $-14+$ cis- 9 & 109.3 & 230.7 & 126.0 & 252.1 & 16.07 & 0.18 & $<0.001$ & 0.86 \\
\hline $\mathrm{C} 18: 1$ cis $-11+$ trans -15 & 11.8 & 13.1 & 12.7 & 13.4 & 0.83 & 0.30 & 0.09 & 0.59 \\
\hline C18:1 cis-12 & 2.0 & 8.9 & 2.3 & 10.9 & 0.67 & 0.10 & $<0.001$ & 0.24 \\
\hline C18:3n-3 & 3.9 & 5.4 & 3.5 & 5.6 & 0.39 & 0.60 & $<0.001$ & 0.24 \\
\hline C18:2 cis-9,trans-11 CLA & 12.0 & 9.1 & 17.0 & 12.9 & 2.73 & 0.01 & 0.05 & 0.72 \\
\hline C18:2 trans-10, cis-12 CLA & 0.13 & 0.18 & 0.14 & 0.18 & 0.02 & 0.81 & 0.09 & 0.73 \\
\hline $\mathrm{C} 20: 5 \mathrm{n}-3$ & 2.1 & 0.7 & 1.7 & 0.7 & 0.28 & 0.34 & $<0.001$ & 0.42 \\
\hline C22:6n-3 & 1.7 & 0.4 & 1.8 & 0.4 & 0.39 & 0.85 & $<0.001$ & 0.95 \\
\hline
\end{tabular}

${ }^{1} \mathrm{BF}=$ barley-based diet supplemented with fish oil; $\mathrm{BS}=$ barley-based diet supplemented with soybean oil; CF = corn-based diet supplemented with fish oil; and CS = corn-based diet supplemented with soybean oil.

${ }^{2}$ Grain = source of dietary grain (barley vs. corn); Oil = source of supplemental oil (fish vs. soy); Grain $\times$ oil $=$ interaction. 
eicosapentaenoic acid (C20:5n-3; 1.9 vs. $0.7 \mathrm{~g} / \mathrm{d})$ and docosahexaenoic acid (C22:6n-3; 1.8 vs. $0.4 \mathrm{~g} / \mathrm{d})$ increased in fish oil- versus soybean oil-supplemented diets, whereas secretion of C18:2 (18.2 vs. $31.3 \mathrm{~g} / \mathrm{d}$; $P<0.001)$ and $\mathrm{C} 18: 3$ (3.7 vs. $5.5 \mathrm{~g} / \mathrm{d} ; P<0.001)$ decreased in diets containing fish oil as compared with those containing soybean oil, respectively.

Treatments did not affect BW or BCS changes over the experimental periods (Table 4). However, an interaction of main treatment effects occurred for BFT changes $(P=0.03)$; fish oil increased BFT by $4.0 \mathrm{~mm}$ compared with soybean oil when combined with cornbased diets but had the opposite effect (reducing BFT by $1.4 \mathrm{~mm}$ compared with soybean oil) for barley-based diets.

Table 4 shows results of indirect MHP calculations. The type of grain did not affect MHP and was 18.3 versus $18.0 \mathrm{Mcal} / \mathrm{d}$ in barley- versus corn-based diets, respectively, which accounted for $29.9 \%$ of ME intake. Consistent with the results reported for DMI and milk yield, fish oil-supplemented diets decreased MHP by $18.5 \%$ compared with the soybean oil-supplemented diets (16.3 vs. $20.0 \mathrm{Mcal} / \mathrm{d} ; P=0.002)$. Moreover, efficiency of ME intake to be converted to milk energy was similar for all diets at an average of $44.9 \%$. Neither energy balance nor efficiencies for milk production were affected by grain type, oil supplement, or their interaction.

Blood metabolic parameters, including glucose, insulin, NEFA, high-density lipoprotein cholesterol, or insulin-to-glucose and NEFA-to-cholesterol ratios were not affected by dietary treatments (Table 5). Triglyceride and very-low-density lipoprotein cholesterol concentrations were not affected by grain type, but feeding fish oil versus soybean oil increased both plasma triacylglycerols (11.5 vs. $10.1 \mathrm{mg} / \mathrm{dL} ; P=0.007)$ and verylow-density lipoprotein cholesterol (2.3 vs. $2.0 \mathrm{mg} / \mathrm{dL}$; $P=0.007)$, respectively. A significant interaction of dietary grain type and oil supplement was observed for plasma concentration of cholesterol $(P=0.01)$, indicat-

Table 4. Metabolic heat production (MHP), tissue gain, and calculated energy balance and partitioning as influenced by grain and oil sources

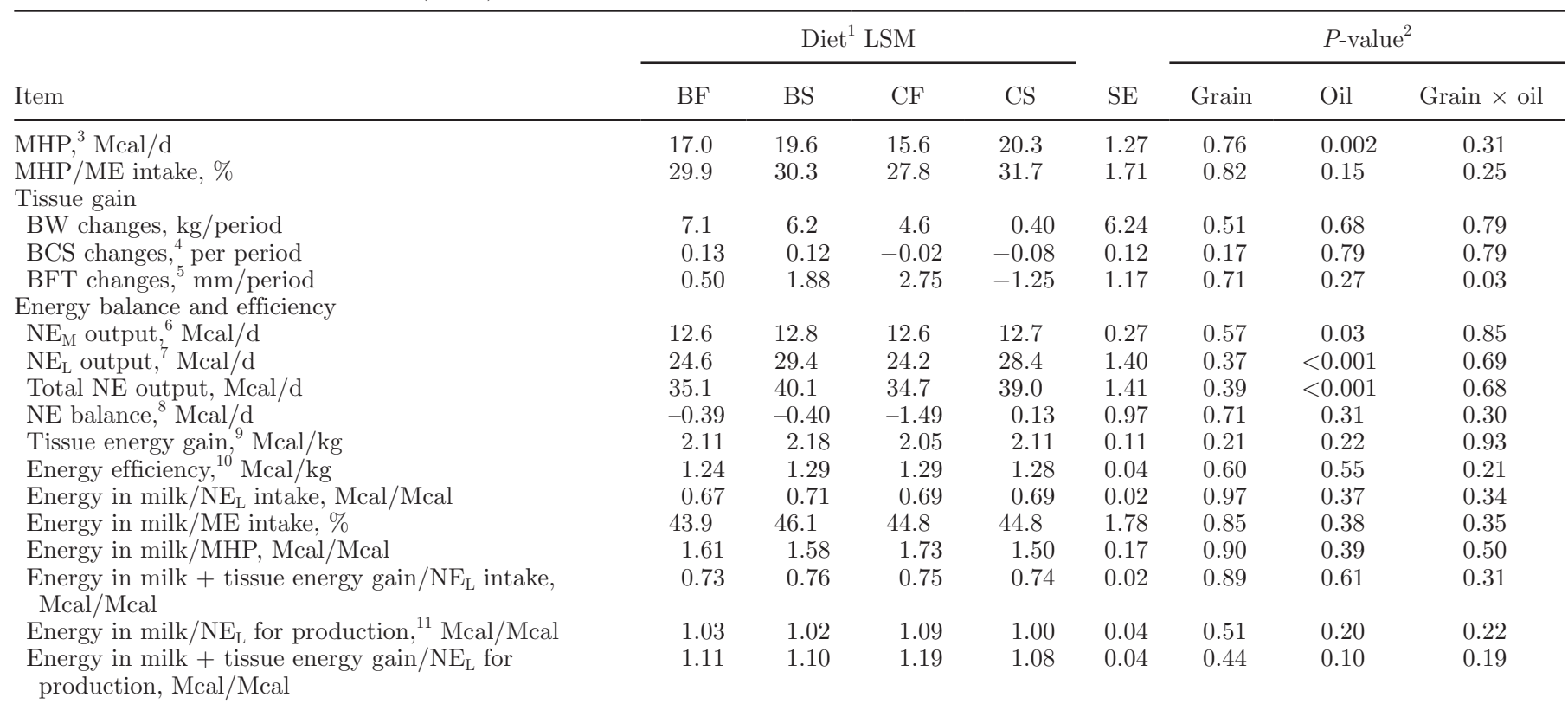

${ }^{1} \mathrm{BF}=$ barley-based diet supplemented with fish oil; $\mathrm{BS}=$ barley-based diet supplemented with soybean oil; $\mathrm{CF}=$ corn-based diet supplemented with fish oil; and CS = corn-based diet supplemented with soybean oil.

${ }^{2}$ Grain $=$ source of dietary grain (barley vs. corn); Oil = source of supplemental oil (fish vs. soy); Grain $\times$ oil $=$ interaction.

${ }^{3}$ Metabolic heat production $=(\mathrm{ME}$ intake, Mcal $/ \mathrm{d})-\left[\left(\right.\right.$ milk energy, Mcal of $\left.\mathrm{NE}_{\mathrm{L}}\right)+\left(\right.$ tissue energy gain or loss, Mcal of $\left.\mathrm{NE}_{\mathrm{L}}\right)+($ maintenance energy, Mcal of $\mathrm{NE}_{\mathrm{L}}$ )] (Moallem et al., 2010).

${ }^{4}$ Body condition score was determined using a 5 -scale method where $1=$ emaciated and $5=$ obese (Ferguson et al., 1994).

${ }^{5}$ Backfat thickness was measured using an ultrasonographic method (Kargar et al., 2013).

${ }^{6} \mathrm{NE}$ for maintenance $=\left(0.08 \times \mathrm{BW}^{0.75}\right) \times 1.2(\mathrm{NRC}, 1981,2001)$.

${ }^{7} \mathrm{NE}$ for lactation $=[0.0929 \times$ fat $(\%)+0.0563 \times$ protein $(\%)+0.0395 \times$ lactose $(\%)] \times$ milk yield $(\mathrm{kg})(\mathrm{NRC}, 2001)$.

${ }^{8} \mathrm{NE}$ balance $=\left(\right.$ energy intake, Mcal of $\left.\mathrm{NE}_{\mathrm{L}}\right)-\left[\left(\right.\right.$ maintenance energy, Mcal of $\left.\mathrm{NE}_{\mathrm{L}}\right)+\left(\right.$ milk energy, Mcal of $\left.\left.\mathrm{NE}_{\mathrm{L}}\right)\right]\left(\mathrm{NRC}_{2} 2001\right)$.

${ }^{9} \mathrm{NE}_{\mathrm{L}}$ gain calculated from BW gain (NRC, 2001).

${ }^{10}$ Energy efficiency $=\left(\right.$ milk energy, Mcal of $\mathrm{NE}_{\mathrm{L}}+$ tissue energy gain or loss, Mcal of $\left.\mathrm{NE}_{\mathrm{L}}\right) / \mathrm{kg}$ of DM.

${ }^{11} \mathrm{NE}_{\mathrm{L}}$ for production $=\mathrm{NE}_{\mathrm{L}}$ intake - energy required for maintenance. 
Table 5. Blood plasma biochemical parameters as influenced by grain and oil sources

\begin{tabular}{|c|c|c|c|c|c|c|c|c|}
\hline Item $^{1}$ & \multicolumn{4}{|c|}{$\operatorname{Diet}^{2}$ LSM } & $\mathrm{SE}$ & \multicolumn{3}{|c|}{$P$-value ${ }^{3}$} \\
\hline \multicolumn{9}{|l|}{ Metabolic parameters } \\
\hline Glucose, $\mathrm{mg} / \mathrm{dL}$ & 48.7 & 46.0 & 49.0 & 49.3 & 2.20 & 0.34 & 0.52 & 0.45 \\
\hline Insulin:glucose & 0.256 & 0.265 & 0.254 & 0.263 & 0.024 & 0.93 & 0.71 & 0.99 \\
\hline NEFA, $\mathrm{mEg} / \mathrm{L}$ & 0.159 & 0.159 & 0.175 & 0.161 & 0.020 & 0.64 & 0.72 & 0.73 \\
\hline HDL, mg/dL & 43.3 & 36.3 & 42.3 & 46.8 & 4.17 & 0.25 & 0.75 & 0.16 \\
\hline $\mathrm{LDL}, \mathrm{mg} / \mathrm{dL}$ & $101.9^{\mathrm{ab}}$ & $81.7^{\mathrm{b}}$ & $99.4^{\mathrm{ab}}$ & $103.1^{\mathrm{a}}$ & 11.14 & 0.08 & 0.12 & 0.04 \\
\hline VLDL, mg/dL & 2.3 & 1.9 & 2.3 & 2.1 & 0.11 & 0.51 & 0.007 & 0.25 \\
\hline RQUICKI & 0.53 & 0.54 & 0.54 & 0.53 & 0.017 & 0.81 & 0.98 & 0.72 \\
\hline \multicolumn{9}{|l|}{ Enzymatic parameters } \\
\hline $\mathrm{AST}, \mathrm{U} / \mathrm{L}$ & $58.9^{\mathrm{a}}$ & $46.1^{\mathrm{b}}$ & $56.5^{\mathrm{a}}$ & $51.8^{\mathrm{ab}}$ & 2.45 & 0.42 & 0.004 & 0.06 \\
\hline $\mathrm{MDA}, \mathrm{nmol} / \mathrm{mL}$ & 1.91 & 1.51 & 1.86 & 1.48 & 1.12 & 0.82 & 0.05 & 0.99 \\
\hline $\mathrm{CD}_{\text {Baseline }}, \mathrm{nmol} / \mathrm{mL}$ & $7.53^{\mathrm{ab}}$ & $7.55^{\mathrm{ab}}$ & $8.01^{\mathrm{a}}$ & $7.10^{\mathrm{b}}$ & 0.21 & 0.93 & 0.03 & 0.02 \\
\hline $\mathrm{CD}_{\text {Max }}, \mathrm{nmol} / \mathrm{mL}$ & $10.24^{\mathrm{ab}}$ & $10.42^{\mathrm{ab}}$ & $11.02^{\mathrm{a}}$ & $9.90^{\mathrm{b}}$ & 0.28 & 0.59 & 0.06 & 0.01 \\
\hline $\mathrm{CD}_{\mathrm{AUC}}, \mathrm{nmol} / \mathrm{mL} \times 90 \mathrm{~min}$ & $23.55^{\mathrm{ab}}$ & $23.82^{\mathrm{ab}}$ & $25.05^{\mathrm{a}}$ & $22.41^{\mathrm{b}}$ & 0.59 & 0.93 & 0.06 & 0.02 \\
\hline
\end{tabular}

${ }^{\mathrm{a}, \mathrm{b}}$ Means within a row with different superscripts differ $(P \leq 0.05)$.

${ }^{1} \mathrm{TAG}=$ triacylglycerols; HDL $=$ high-density lipoprotein cholesterol; LDL $=$ low-density lipoprotein cholesterol; VLDL $=$ very-low-density lipoprotein cholesterol; RQUICKI = the revised quantitative insulin sensitivity check index; AST = aspartate transaminase; ALT = alanine transaminase; $\mathrm{ALP}=$ alkaline phosphatase; $\mathrm{CK}=$ creatine kinase; $\mathrm{TAS}=$ total antioxidant status; $\mathrm{MDA}=$ malondialdehyde; $\mathrm{CD}=$ conjugated dienes; $\mathrm{AUC}=$ area under the curve.

${ }^{2} \mathrm{BF}$ = barley-based diet supplemented with fish oil; $\mathrm{BS}=$ barley-based diet supplemented with soybean oil; $\mathrm{CF}=$ corn-based diet supplemented with fish oil; and CS = corn-based diet supplemented with soybean oil.

${ }^{3}$ Grain $=$ source of dietary grain (barley vs. corn); Oil = source of supplemental oil (fish vs. soy); Grain $\times$ oil $=$ interaction.

ing plasma concentration of cholesterol was increased when fish oil was supplemented in barley-based diets only. Furthermore, an interaction of main treatment effects occurred for plasma concentrations of low-density lipoprotein cholesterol $(P=0.04)$. Barley-based diets tended $(P=0.08)$ to decrease plasma concentration of low-density lipoprotein cholesterol (91.8 vs. 101.3 $\mathrm{mg} / \mathrm{dL}$ ) compared with corn-based diets for cows fed soybean oil but not for cows fed fish oil.

Table 5 shows the plasma activity of circulating enzymes originating from the liver. Plasma activity of ALT did not vary significantly with dietary treatments. Interaction between grain type and oil supplement tended $(P=0.06)$ to be significant for AST and CK. Plasma AST activity was $27.8 \%$ greater in cows fed barley- but not corn-based diets that were supplemented with fish oil versus soybean oil $(P=0.004)$. Plasma activity of ALP was decreased $25.1 \%$ in cows fed barley-based compared with cows fed corn-based diets (48.6 vs. $64.9 \mathrm{U} / \mathrm{L} ; P=0.004)$. Feeding fish oil almost doubled plasma ALP activity as compared with soybean oil ( 75.4 vs. $38.1 \mathrm{U} / \mathrm{L} ; P<0.001)$.

The susceptibility of plasma lipids to lipoperoxidation was determined by monitoring the in vitro $\mathrm{CD}$ generation induced by copper salts (Table 5). Interactions between grain type and oil supplement occurred for basal $(P=0.02)$ and maximum $(P=0.01) \mathrm{CD}$ production and calculated area under the curve $(P$ $=0.02)$. In cows fed corn- but not barley-based diets supplemented with fish oil versus soybean oil, basal (8.01 vs. $7.10 \mathrm{nmol} / \mathrm{mL}$ ) and maximum (11.02 vs. 9.90 $\mathrm{nmol} / \mathrm{mL}$ ) CD production as well as calculated area under the curve $(25.05$ vs. $22.41 \mathrm{nmol} / \mathrm{mL} \times 90 \mathrm{~min})$ were increased. Plasma total antioxidant status was not affected by treatment. Plasma MDA was measured to determine the relative intensity of in vivo plasma lipoperoxidation in cows. Results showed that cows fed fish oil-supplemented diets produced greater MDA (1.89 vs. $1.50 \mathrm{nmol} / \mathrm{mL} ; P=0.05)$, which indicated the balance between the oxidants and antioxidants favors the former.

\section{Correlations Between DMI and Blood Biochemical Parameters}

In the current experiment, DMI had strong positive correlations with plasma insulin $(\mathrm{r}=0.66 ; P \leq 0.01$; Table 6) and ALT $(\mathrm{r}=0.40 ; P \leq 0.05)$ and tended 
$(P \leq 0.10)$ to have positive correlations with plasma glucose $(r=0.32)$, insulin:glucose $(r=0.31)$, total antioxidant status $(\mathrm{r}=0.33)$, and high-density lipoprotein cholesterol $(\mathrm{r}=0.26)$. Furthermore, DMI showed negative correlations with plasma NEFA $(\mathrm{r}=-0.44 ; P$ $\leq 0.01)$, NEFA:cholesterol $(\mathrm{r}=-0.37 ; P \leq 0.05)$, and ALP $(\mathrm{r}=-0.45 ; P \leq 0.01)$ and tended to have negative correlation with plasma MDA $(\mathrm{r}=-0.26 ; P \leq 0.10)$, which had a positive correlation with plasma AST $(\mathrm{r}=$ $0.38 ; P \leq 0.05)$.

\section{DISCUSSION}

Climatic data revealed that animals experienced a mild degree of heat stress throughout the experimental period (Armstrong, 1994). Physiological responses of high-producing dairy cows to heat stress in terms of reduced DMI and milk production and also increased maintenance energy requirements start to take place at a THI of approximately 72 (Armstrong, 1994) or 68 (Bernabucci et al., 2010). Rectal temperature of dairy cows normally ranged from 38.3 to $38.7^{\circ} \mathrm{C}$, indicating heat stress and insufficient thermoregulation in the current situation because rectal temperature averaged $38.9^{\circ} \mathrm{C}$ in the current experiment irrespective of treatment. Similarly, Liu et al. (2008) measured $39.0^{\circ} \mathrm{C}$ rectal temperature in heat-stressed cows, which was reduced by $0.6^{\circ} \mathrm{C}$ when CLA-supplemented cows experienced MFD. Cows fed fish oil tended $(P<0.08)$ to have a decreased respiration rate relative to cows fed soybean oil (58 vs. 62 breaths/min), probably because of lower DMI.

Lipoperoxidation of plasma FA was assessed in vitro using copper-induced oxidation and monitoring the production of $\mathrm{CD}$ in whole plasma. This approach is useful because it reflects the balance between pro- and antioxidant factors in blood (Scislowski et al., 2005). Results suggested that in corn-based diets, plasma FA of cows supplemented with soybean oil versus fish oil were more resistant against peroxidation, which was obvious from reduced basal and maximum CD as well as lower calculated area under the curve (interaction $=P<0.05$; Table 5). However, in vivo parameters did not confirm this interaction between the type of grain and oil source but rather suggested a generally increased susceptibility to peroxidation when feeding fish oil rather than soybean oil (e.g., increased MDA concentration as well as ALP and AST activities). In an experiment performed by Ronchi et al. (1999) plasma ALP activity increased in feed-restricted heifers in a thermoneutral environment. They attributed this effect to increased liver activity to support the typical metabolism of reduced DMI in cattle, which might have been similar here because DMI was depressed by fish

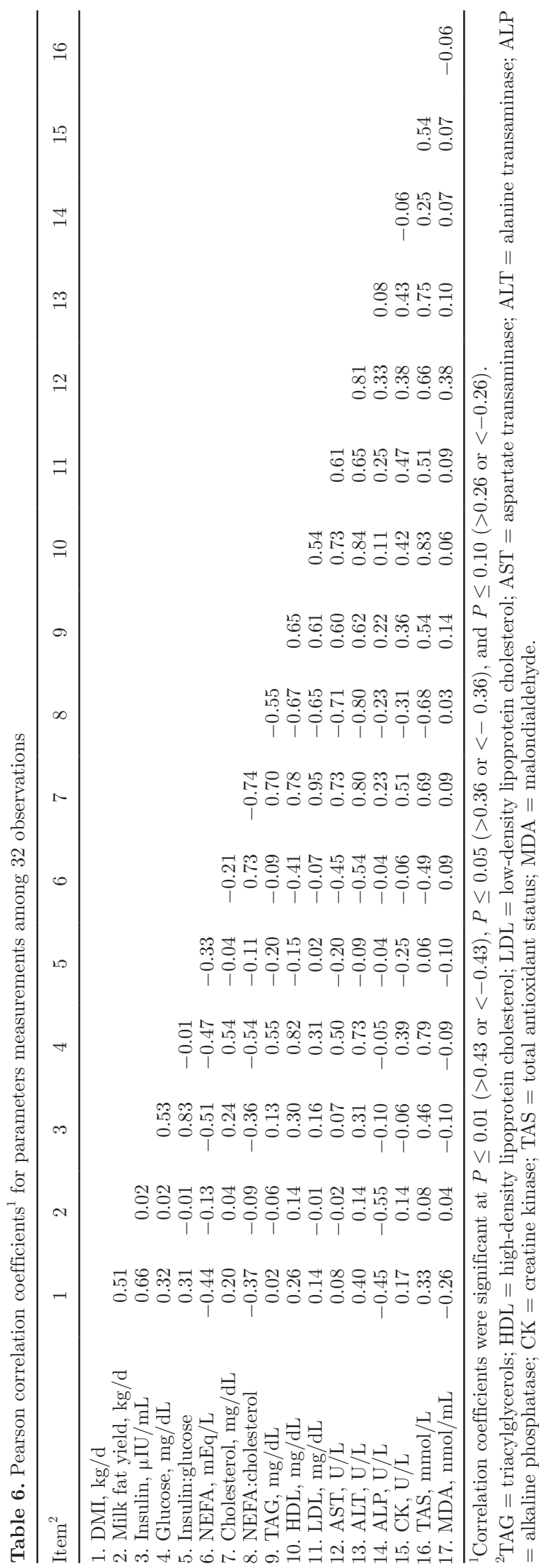

Journal of Dairy Science Vol. 98 No. 7, 2015 
oil- versus soybean oil-supplemented diets $(P<0.001)$. Possibly, decreased DMI of cows fed fish oil- versus soybean oil-supplemented diets may not be a maladaptive response but rather an organized strategy that strives to avoid excessive oxidation and free radical formation. This description is associated with the oxygen consumption theory, which suggests that animals consume net energy at a rate that optimizes the use of oxygen and minimizes production of free radicals (Ketelaars and Tolkamp, 1996). Therefore, it might be concluded that reduced DMI in heat-stressed cows supplemented with fish oil is associated with partial liver dysfunction, which is evidenced by increased plasma activities of AST and ALP as well as an increase in plasma MDA. Simultaneously, decreased DMI of cows fed fish oil led to an $18.5 \%$ decrease in MHP compared with cows fed soybean oil (Table 4).

The severity of reduction in milk fat yield was greater in fish oil-supplemented cows compared with soybean oil-supplemented cows. This was related to a 2.6-fold increase in the milk secretion of trans-10 C18:1 isomer $(41.8$ vs. $16.0 \mathrm{~g} / \mathrm{d} ; P<0.001)$, which showed a high negative correlation with milk fat yield $(\mathrm{r}=-0.38$; $P \leq 0.05)$ and also to 2.8 - and 2.1-fold decrease in the milk secretion of $\mathrm{C} 18: 0(\mathrm{r}=0.79 ; P \leq 0.01)$ and cis-9 C18:1 ( $\mathrm{r}=0.82 ; P \leq 0.01)$, respectively, which showed a strong positive correlation with milk fat yield (Alizadeh et al., 2012).

An observed interaction between dietary grain type and oil supplement on BFT might be attributed to a significant interaction of main treatment effects observed for intake of particles retained on 19-mm sieve (Kargar et al., 2013). Fish oil increased intake of particles retained on $19-\mathrm{mm}$ sieve by $0.2 \mathrm{~kg}$ compared with soybean oil when combined with barley-based diets but had the opposite effect (reducing intake by $0.7 \mathrm{~kg}$ compared with soybean oil) for corn-based diets. Because particles retained on the top sieve of the Penn State Particle Separator are bulky with low energy density, it is assumed that cows fed these particles would receive feed with slightly less energy and thereby would have lesser BFT.

As reported by Purwanto et al. (1990), MHP is increased as milk production is enhanced. Because of less DMI and milk yield as well as severe MFD, total energy output (including both $\mathrm{NE}_{\mathrm{M}}$ and $\mathrm{NE}_{\mathrm{L}}$ ) was reduced $11.9 \%$ for cows fed fish oil- versus soybean oil-supplemented diets (34.9 vs. $39.6 \mathrm{Mcal} / \mathrm{d} ; P<0.001)$. However, when taking the energy deposition in body mass into account, efficiency tended $(P=0.10)$ to increase by $5.5 \%$ in fish oil-supplemented diets compared with soybean oil-supplemented diets. This finding indicates different partitioning of energy between oil supplements and is consistent with the suggestion of others (Van
Soest, 1963; Moallem et al., 2010) that milk fat-depressing diets enhance the priority of BW gain at the expense of milk yield.

It has been shown that environmental heat load changes metabolism differently than would be anticipated based upon calculated whole-body energy balance (Baumgard and Rhoads, 2012). In an experiment by Ronchi et al. (1999), heat-stressed heifers that were in negative energy balance did not lose body condition as much as did their pair-fed, thermal-neutral counterparts. Results of previous experiments have demonstrated that basal plasma NEFA concentrations are typically decreased in heat-stressed heifers and cows despite noticeable decrease in DMI, especially when compared with pair-fed, thermal-neutral counterparts (Ronchi et al., 1999; Wheelock et al., 2010; Baumgard et al., 2011). This may suggest that heat-stressed cows have increased lipid retention in their adipose tissues because they have shown a blunted NEFA response to an epinephrine challenge compared with pair-fed, thermal-neutral counterparts (Baumgard et al., 2011). These observations correspond with results obtained from a heat-stressed rodent model showing decreases in in vivo lipolytic rates and in vitro lipolytic enzyme activity (Torlinska et al., 1987, cited in Baumgard and Rhoads, 2012). Furthermore, environmental-induced hyperthermia increases adipose tissue lipoprotein lipase activity (Christon, 1988, cited in Baumgard and Rhoads, 2012), indicating adipose tissue of heatstressed animals has an enhanced ability to release FA from circulating triglycerides for storage (Baumgard and Rhoads, 2012). The blunted lipolytic capacity of adipose tissue is particularly uncommon as cows subjected to environmental-induced hyperthermia are severely energy restricted (i.e., 30-40\%), in a calculated negative energy balance (roughly -5 Mcal; Moore et al., 2005; Wheelock et al., 2010; Baumgard et al., 2011), and lose significant BW (Wheelock et al., 2010; Baumgard et al., 2011). Although loss of BW supported the calculated net energy balance in their experiments, the proportion of reduced BW due to decreased DMI is not clear yet. In the current experiment, the observed tissue gain for at least 3 of the 4 experimental diets despite calculated negative energy balance may indicate that cows actually were in positive energy balance and explains the difficulty in accurately estimating energy balance during heat stress. Taken together, it is likely that net energy balance, in the current experiment, has been underestimated because the beneficial effects of diets on digestibility energetics (Baumgard et al., 2011) and severity of heat stress on increased maintenance costs are currently not incorporated into the NRC (2001) energy-balance equations. 
Similar plasma glucose and insulin and the ratio of insulin to glucose may indicate that glucose and insulin are influenced equally by both diets based on either a rapidly degradable starch type (barley grain) or a slowly degradable starch type (corn grain). Insulin sensitizing activity is mainly attributed to less body fat mobilization and lower plasma NEFA concentrations. Recently, it has been reported (Roche et al., 2009) that mobilization of high amounts of body reserves is associated with drastic insulin resistance. We speculated that decreased DMI in cows fed barley-based diets and diets supplemented with fish oil would increase body reserve mobilization and plasma NEFA concentration and thereby decrease insulin sensitivity. Irrespective of the effect of experimental diets on MFD, the RQUICKI index values were not affected, suggesting that all diets had a similar effect on insulin sensitivity. Of course, it is possible that the effects of CLA-inducing diets on peripheral-tissue insulin responsiveness are subtle and cannot be detected using techniques such as the RQUICKI index in lactating dairy cows.

Observed increase in plasma AST activity of cows supplemented with fish oil confirmed previous reports on dairy cows given diets rich in n-3 (Gobert et al., 2009). Furthermore, increased concentrations of plasma AST and CK were observed in heat-stressed cows (Liu et al., 2008). They attributed this effect to hemolysis and muscle damage as the result of a negative energy balance. However, cows in the current experiment did not experience negative energy balance due to observed tissue gain. Liu et al. (2008) showed that administration of a CLA supplement (containing equal proportions of main CLA isomers, including cis-9,trans-11 and trans10, cis-12) to dairy cows resulted in increased milk CLA secretion and lower plasma AST and CK, indicating CLA protective effect on body damage in hot weather. Although milk fat yield reduced in CLA-supplemented diets, DMI and plasma activity of ALP and ALT of heat-stressed cows remained unchanged (Liu et al., 2008). They also observed improved electrolyte balance (elevated concentrations of plasma $\mathrm{Na}, \mathrm{K}, \mathrm{Cl}$, and $\mathrm{Ca}$ ) in cows supplemented with CLA compared with control cows. Because of a strong correlation between plasma ALP and DMI ( $\mathrm{r}=-0.45 ; P \leq 0.01)$, the negative balance of calcium may be, in part, attributed to the lower DMI in cows fed fish oil-supplemented diets compared with cows fed soybean oil-supplemented diets.

\section{CONCLUSIONS}

Cows in this study were stressed by a mild degree of environmentally induced hyperthermia as indicated by THI, respiration rate, and rectal temperature. Experimental diets induced a moderate MFD regardless of environmental heat load but had no effect on milk yield or milk solids except for fish oil versus soybean oil, which reduced milk yield, which was associated with a reduction in milk lactose secretion and DMI. Plasma activity of circulating enzymes including AST and ALP as well as plasma MDA increased for cows fed fish oilsupplemented diets, which are associated with partial liver dysfunction. Supplementing soybean oil versus fish oil could moderate heat-stress conditions in dairy cows through maintaining plasma enzyme activities, decreasing susceptibility of plasma lipids to oxidation, and maintaining DMI and thereby milk yield. Overall, in cows fed diets supplemented with soybean oil versus fish oil, biosynthesis in the mammary gland was prioritized over anabolism and oxidation in peripheral adipose and muscle tissues, regardless of type of grain used.

\section{ACKNOWLEDGMENTS}

The authors express their kind appreciation to the farm staff at Lavark, the farm animal research and teaching unit (IUT), for diligent animal care; to Mohsen Babashahi, Farzad Hashemzadeh-Cigari, Azizollah Bakhtari, and Hamed Beiranvand (IUT) for their help in conducting this experiment; and to several students from the IUT completing course requirements for their input to the research and laboratory analyses.

\section{REFERENCES}

AbuGhazaleh, A. A., D. J. Schingoethe, A. R. Hippen, K. F. Kalscheur, and L. A. Whitlock. 2002. Fatty acid profiles of milk and rumen digesta from cows fed fish oil, extruded soybeans or their blend. J. Dairy Sci. 85:2266-2276.

Ackman, R. G., and J. C. Sipos. 1964. Application of specific response factors in the gas chromatographic analysis of methyl esters of fatty acids with flame ionization detectors. J. Am. Oil Chem. Soc. 41:377-378.

Alizadeh, A. R., M. Alikhani, G. R. Ghorbani, H. R. Rahmani, L. Rashidi, and J. J. Loor. 2012. Effects of feeding roasted safflower seeds (variety IL-111) and fish oil on dry matter intake, performance and milk fatty acid profiles in dairy cattle. J. Anim. Physiol. Anim. Nutr. (Berl.) 96:466-473.

Armstrong, D. V. 1994. Heat stress interaction with shade and cooling. J. Dairy Sci. 77:2044-2050.

Bauman, D. E., and W. B. Currie. 1980. Partitioning of nutrients during pregnancy and lactation: A review of mechanisms involving homeostasis and homeorhesis. J. Dairy Sci. 63:1514-1529.

Baumgard, L. H., and R. P. Rhoads. 2012. Ruminant production and metabolic responses to heat stress. J. Anim. Sci. 90:1855-1865.

Baumgard, L. H., J. B. Wheelock, S. R. Sanders, C. E. Moore, H. B. Green, M. R. Waldron, and R. P. Rhoads. 2011. Postabsorptive carbohydrate adaptations to heat stress and monensin supplementation in lactating Holstein cows. J. Dairy Sci. 94:5620-5633.

Bernabucci, U., N. Lacetera, L. H. Baumgard, R. P. Rhoads, B. Ronchi, and A. Nardone. 2010. Metabolic and hormonal acclimation to heat stress in domesticated ruminants. Animal 4:1167-1183.

Cabrita, A. R. J., J. M. P. Vale, R. J. B. Bessa, R. J. Dewhurst, and A. J. M. Fonseca. 2009. Effects of dietary starch source and buffers on milk responses and rumen fatty acid biohydrogenation in 
dairy cows fed maize silage-based diets. Anim. Feed Sci. Technol. 152:267-277.

Chouinard, P. Y., V. Girard, and G. J. Brisson. 1997. Performance and profiles of milk fatty acids of cows fed full fat, heat-treated soybeans using various processing methods. J. Dairy Sci. 80:334-342.

Christon, R. 1988. The effect of tropical ambient temperature on growth and metabolism in pigs. J. Anim. Sci. 66:3112-3123.

Drackley, J. K., T. M. Cicela, and D. W. LaCount. 2003. Responses of primiparous and multiparous Holstein cows to additional energy from fat or concentrate during summer. J. Dairy Sci. 86:13061314.

Ferguson, J. D., D. T. Galligan, and N. Thomsen. 1994. Principal descriptors of body condition score in Holstein cows. J. Dairy Sci. 77:2695-2703

Gobert, M., B. Martin, A. Ferlay, Y. Chilliard, B. Graulet, P. Pradel, D. Bauchart, and D. Durand. 2009. Plant polyphenols associated with vitamin $\mathrm{E}$ can reduce plasma lipoperoxidation in dairy cows given n-3 polyunsaturated fatty acids. J. Dairy Sci. 92:6095-6104.

Holtenius, P., and K. Holtenius. 2007. Brief communication: A model to estimate insulin sensitivity in dairy cows. Acta Vet. Scand. 49:29-31

Kargar, S., G. R. Ghorbani, M. Alikhani, M. Khorvash, L. Rashidi, and D. J. Schingoethe. 2012. Lactational performance and milk fatty acid profile of Holstein cows in response to dietary fat supplements and forage:concentrate ratio. Livest. Sci. 150:274-283.

Kargar, S., G. R. Ghorbani, and M. Khorvash. 2014a. Nutrient digestibility, rumen fermentation parameters, and production performance in response to dietary grain source and oil supplement of Holstein dairy cows. Iran J. Anim. Sci. Res. (Accepted) (In Persian).

Kargar, S., G. R. Ghorbani, M. Khorvash, E. Kamalian, and D. J Schingoethe. 2013. Dietary grain source and oil supplement: Feeding behavior and lactational performance of Holstein cows. Livest. Sci. 157:162-172

Kargar, S., G. R. Ghorbani, M. Khorvash, A. Sadeghi-Sefidmazgi, and D. J. Schingoethe. 2014b. Reciprocal combinations of barley and corn grains in oil-supplemented diets: Feeding behavior and milk yield of lactating cows . J. Dairy Sci. 97:7001-7011.

Ketelaars, J. J. M. H., and B. J. Tolkamp. 1996. Oxygen efficiency and the control of energy flow in animals and humans. J. Anim. Sci. 74:3036-3051.

Liu, Z. L., P. Chen, J. M. Li, S. B. Lin, D. M. Wang, L. P. Zhu, and D. P. Yang. 2008. Conjugated linoleic acids (CLA) moderate negative responses of heat-stressed cows. Livest. Sci. 118:255-261.

Mirzaei, M., G. R. Ghorbani, M. Khorvash, H. R. Rahmani, and A. Nikkhah. 2011. Chromium improves production and alters metabolism of early lactation cows in summer. J. Anim. Physiol. Anim. Nutr. (Berl.) 95:81-89.

Moallem, U., G. Altmark, H. Lehrer, and A. Arieli. 2010. Performance of high-yielding dairy cows supplemented with fat or concentrate under hot and humid climates. J. Dairy Sci. 93:3192-3202.

Mohammed, R., J. J. Kennelly, J. K. G. Kramer, K. A. Beauchemin C. S. Stanton, and J. J. Murphy. 2010. Effect of grain type and processing method on rumen fermentation and milk rumenic acid production. Animal 4:1425-1444.

Moore, C. E., J. K. Kay, R. J. Collier, M. J. VanBaale, and L. H. Baumgard. 2005. Effect of supplemental conjugated linoleic acids on heat-stressed Brown Swiss and Holstein cows. J. Dairy Sci. 88:1732-1740.

NRC. 1981. Effect of Environment on Nutrient Requirements of Domestic Animals. Natl. Acad. Press, Washington, DC.
NRC. 2001. Nutrient Requirements of Dairy Cattle. 7th rev. ed. Natl. Acad. Sci., Washington, DC.

Purwanto, B. P., Y. Abo, R. Sakamato, F. Furumoto, and S. Yamamoto. 1990. Diurnal patterns of heat production and heart rate under thermoneutral conditions in Holstein Friesian cows differing in milk production. J. Agric. Sci. 114:139-142.

Rhoads, M. L., J. W. Kim, R. J. Collier, B. A. Crooker, Y. R. Boisclair, L. H. Baumgard, and R. P. Rhoads. 2010. Effects of heat stress and nutrition on lactating Holstein cows: II. Aspects of hepatic growth hormone responsiveness. J. Dairy Sci. 93:170-179.

Rhoads, R. P., A. J. La-Noce, J. B. Wheelock, and L. H. Baumgard. 2011. Short communication: Alterations in expression of gluconeogenic genes during heat stress and exogenous bovine somatotropin administration. J. Dairy Sci. 94:1917-1921.

Roche, J. R., N. C. Friggens, J. K. Kay, M. W. Fisher, K. J. Stafford, and D. P. Berry. 2009. Invited review: Body condition score and its association with dairy cow productivity, health, and welfare. J. Dairy Sci. 92:5769-5801.

Ronchi, B., U. Bernabucci, N. Lacetera, A. Verini-Supplizi, and A. Nardone. 1999. Distinct and common effects of heat stress and restricted feeding on metabolic status in Holstein heifers. Zoot. Nutr. Anim. 25:11-25.

SAS Institute Inc. 2003. SAS User's Guide. Version 9.1. SAS Inst. Inc. Cary, NC.

Schnitzer, E., I. Pinchuk, A. Bor, M. Fainaru, A. M. Samuni, and D. Lichtenberg. 1998. Lipid oxidation in unfractionated serum and plasma. Chem. Phys. Lipids 92:151-170.

Scislowski, V., D. Bauchart, D. Gruffat, P. M. Laplaud, and D. Durand. 2005. Effects of dietary n-6 or n-3 polyunsaturated fatty acids protected or not against ruminal hydrogenation on plasma lipids and their susceptibility to peroxidation in fattening steers. J. Anim. Sci. 83:2162-2174.

Stefanov, I., B. Vlaeminck, and V. Fievez. 2010. Short communication: A novel procedure for routine milk fat extraction based on dichloromethane. J. Food Compos. Anal. 23:852-855.

Torlinska, T., R. Banach, J. Paluszak, and A. Gryczka-Dziadecka 1987. Hyperthermia effect on lipolytic processes in rat blood and adipose tissue. Acta. Phys. Pol. 38:361-366.

Van Soest, P. J. 1963. Ruminant fat metabolism with particular reference to factors affecting low milk fat and feed efficiency. A review. J. Dairy Sci. 46:204-216.

Wheelock, J. B., R. P. Rhoads, M. J. VanBaale, S. R. Sanders, and L. H. Baumgard. 2010. Effects of heat stress on energetic metabolism in lactating Holstein cows. J. Dairy Sci. 93:644-655.

Whitlock, L. A. D. J. Schingoethe, A. R. Hippen, K. F. Kalscheur, R. J. Baer, N. Ramaswamy, and K. M. Kasperson. 2002. Fish oil and extruded soybeans fed in combination increase conjugated linoleic acids in milk of dairy cows more than when fed separately. J. Dairy Sci. 85:234-243.

Wolff, R. L., C. C. Bayard, and R. J. Fabien. 1995. Evaluation of sequential methods for the determination of butterfat fatty acid composition with emphasis on trans-18:1 acids: Application to the study of seasonal variations in French butters. J. Am. Oil Chem. Soc. $72: 1471-1483$.

Wullepit, N., M. Hostens, C. Ginneberge, V. Fievez, G. Opsomer, D. Fremaut, and S. DeSmet. 2012. Influence of a marine algae supplementation on the oxidative status of plasma in dairy cows during the periparturient period. Prev. Vet. Med. 103:298-303. 